\title{
VACUUMING THE WHOLE HOUSE AND WHERE DO WE GO NOW: A CONVERSATION WITH JOSHUA FERRIS
}

Here is a dance between a man and some paper: four years after The Iowa Review was founded, Joshua Ferris entered the world; a few decades later, in 1999, a millennium drew to a close and readers opened The Iowa Review to find the short story "Mrs. Blue," Ferris's first published fiction, and to discover, for the first time, a talent that would lead Ferris through a first novel, Then We Came to the End (2007), a PEN/Hemingway Award winner and National Book Award finalist, and a second novel, The Unnamed (2010), just days away from entering the world when we met in New York City, in January 2010, the year of The Iowa Review's fortieth anniversary.

Tara Atkinson: When did you start writing?

Joshua Ferris: I started as a little kid. I think that I was just very taken by Alfred Hitchcock and little detective stories, The Twilight Zone, Edgar Allen Poe. I started to write bad imitations of those things.

I had an early romance with the pen. That sounds very Freudian, but I loved to draw and come up with captions and slugs, and I also pretended to read great big books to my friends before I could read at all, but I was pretending that I had read The Thorn Birds and James Fisher novels when I was five or six. So from a very early age there was always a romance that seemed to hover over words.

TA: Did that have any effect on your choosing the University of Iowa as an undergrad?

JF: No, actually, I came to Iowa as an engineering major, and the guy who was in charge of the general engineering class saw me reading the New York Times; I had been reading the New York Times every day in that class, so he finally said, "Do you want to be an engineer or do you want to read the New York Times?" And I thought it was a very fair question and one that I knew the answer to immediately, which was that I wanted to read the New York Times. 
So I got out of engineering and had the good fortune to be at a place where writing was very alive and I could avail myself of those resources without even having chosen.

TA: So starting out writing imitations, being in love with the written word, how did your reason for writing develop?

JF: Well, I think I just became. I started to read more sophisticated things, and at that point I probably became daunted more than anything. I started to read Nabokov, Dostoevsky, Kafka, you know, at around twelve or thirteen. And Camus. Once I went to a bookstore and I asked for "Cay-muss." I tried to assimilate those, but I really had no critical faculty to do so, and it was the clear brilliance of what I was encountering coupled with my utter lack of understanding that made writing seem like an impossible goal. Really, even reading and understanding seemed like an impossible goal, but I tend to like very difficult tasks, so I was driven by that more than I was deterred. 126 It was probably only when I entered graduate school-so, you know, if I'm thirteen and I'm encountering these difficult writers, it's probably thirteen years-before I'd put in enough time and made some progress to call myself a writer with a legitimate denomination.

TA: You didn't call yourself a writer until you got into an MFA program?

JF: No, it's not a cause and effect relationship. It's very easy to call yourself a banker, it's very easy to call yourself a secretary, it's very easy to call yourself a lawyer. Those things come with a kind of infrastructure that naturally endows legitimacy on that claim. If you have nothing published or haven't acted in something of substance, how do you call yourself a writer or an actor? I think you measure by the time spent doing those things, and by the time I was twenty-six, I'd spent an enormous amount of time writing, and that seemed sufficient, regardless of my publishing record, which at that point was nearly naught.

TA: How was your experience in Iowa? It wasn't a UNEsco City of Literature yet. 
JF: To me it was. There's a reading every day, there were professors and writers who were available and open to hearing anything from their students, and they would introduce me to writers who would then show up at some lecture hall and give a reading, so it wasn't just an abstraction, writers weren't just an abstraction, they were flesh and blood human beings who came to town on a tour, who read and spoke to an audience and engaged them. It gave proof to the idea that there could be such things as working writers. So to me it was like falling into the capital of writing itself. Where else could you find out about Steve Erickson and Mark Strand? I mean, maybe in New York, but one certainly doesn't expect it from a Big Ten school in the middle of Iowa.

TA: About New York: how long have you lived here?

JF: Since 2003.

TA: A lot of people told me not to move here because it's very distracting. But obviously you've made it work.

JF: You have to have an enormous amount of discipline or absolutely no social life, and it's best to have both of those things, because the distractions are monumental and ever-present. This city begs you to live, it demands that you live. Sometimes that can be antithetical to writing. Nobody usually does it very well when they're doing both at the same time. You know, Hemingway had to take a break from the drinking and the fishing and the women when he was writing. Proust had to live the social life of a savant for years and years before it drove him into his cork-lined rooms.

TA: Are there things about New York that you find useful?

JF: Oh, yes. It's ultimately rejuvenating. After you write something, there's no better place to walk out, to feel alive and a part of things. And the cultural life is so very vibrant. There's no better place to find a network of fellow writers. In so many ways it's a very nurturing place, but the work itself is at odds with that impulse because the work itself requires so much time and attention. The city is a guarantor of ADD, and you have to be steeled against your worst impulses. 
TA: Do you think being from the Midwest informs your work at all?

JF: You mean do I have a Protestant work ethic? That's also called salvation fear: if you don't work hard enough you won't make it to heaven. No, I suspect that it's probably just some genetic trait carried on by my mother. My stepfather was a very hard worker, and I imagine it got into me. I did a lot of vacuuming as a child.

Writing is much more enjoyable, but they're sort of similar. You're dealing with a very large, heavy, unwieldy thing and the room looks endless and the activity itself seems pretty pointless until you're all done. The other thing is that you have to finish when you vacuum. If you only vacuum half, you still have a dirty house.

TA: You don't teach, do you?

JF: I don't have to. I make enough that I don't have to; I'd rather write. But of course that may change when my fortunes turn and I have to teach. But I enjoy teaching.

TA: Do you have any comments on MFA programs? Some people are concerned there may be too many of them.

JF: I think that the worry is unfounded. It's another thing to gripe about and maybe, in fact, an indication of a spoiled and inward-looking culture. It's all very hit or miss, the programs and the teachers are all very hit or miss. And it can go horribly, terribly wrong, you can incur a lot of debt, but the truth is if you come with the right intentions and you listen rather than talk and you read a lot and you get the right instructors, you really have no choice but to learn.

I should also add that you learn about everything you could possibly learn in about ten or twenty weeks. So that's, say, a semester. If you have the right instructors, you can learn everything you're going to learn in about a semester, and typical programs are two years, so there is an imbalance there. You learn about your craft, you learn about things like point of view, tense, and things like that and then, you know, it's a finite list, and after you exhaust it, you have to bring to bear your imagination, your empathy, your love of language, your originality on the work itself, and those things can't really 
be taught in a program. So I think what it really comes down to is a misunderstanding of what the programs themselves can provide. People complain because they're confused, because essentially what they're assuming is that the program can have someone else there to do those things. They promote the idea that they can teach you to write, but the best they can do is teach you to be a better reader so you can become a reader of your own work.

TA: When you first published "Mrs. Blue" in The Iowa Review, did you know then that you wanted to write a novel?

JF: Oh, I knew before I wrote "Mrs. Blue," but it seemed like an implausible proposition. The novel is like the young writer's bête noir; it seems like a holy grail, or something. It seems very out of reach.

Another misperception is that people think that short stories prepare you to write the great novel; I don't think that's true. You start a story because its deception is that it's manageable; it sort of presents itself as a more modest goal. So it's not as if the new writer is writing stories just to hone their craft for the Great American Novel. It seems possible to write a story, whereas a novel seems remote at best, remote and despairingly improbable. So, you know, my early stories were an attempt to get a grasp on the chaos that writers face when they're confronted with the enormity of the task.

Maybe I will add this one thing. I think I was twenty-three when "Mrs. Blue" came out in The Iowa Review, and I had no objective legitimacy about what I was doing. And although I didn't need that to continue writing, it did help me. When TIR published "Mrs. Blue," it gave me five years of my life back, five years of my life that I had spent it gave back to me as a dividend, and it gave me five years of a currency of hope, to sustain me. So in so many ways I have a lot to thank TIR for.

TA: Your new novel is coming out next week. Are you nervous about it?

JF: There is the anxiety of the moment, naturally, but I think that's only human and it is mercifully brief. I think I would be somewhat inhuman if I were to be very casual about how it's going to be perceived. Apparently whenever John Cheever sent something to the press he would leave the country because the newspapers couldn't follow you; you'd have to get a cable or something. But if you left the country now you'd still have to con- 
front the computer at Terminal A, so there's no real way to avoid the immediate referendum on your book.

TA: I thought your new novel, The Unnamed, was less funny than Then We Came to the End.

JF: I suspect it's much, much less funny. You would be funny if you thought it was funny.

You know, I wrote a book that was supposedly funny, so I became known as a funny writer, and now I've written a novel that's not so funny, so maybe I'll be known as the guy who doesn't know if he wants to be a funny writer or a not-funny writer. These kinds of labels will attend a writer no matter what he or she decides to do, until they die, at which point the final, critical moniker will be handed down. But I think that the best thing you can do is not worry so much about how these things go. A departure very early from the trip might actually be the trip.

TA: Do you know what you're working on next? Are you at liberty to say?

JF: I'm working on a third novel that I don't know much about. I know almost an inch more than you do, and you know nothing.

TA: Then We Came to the End is about advertising, and you happened to work in advertising. Were you working there at the time that you wrote it?

JF: No, I didn't have the distance to do that.

TA: How would you say that autobiography affects your work?

JF: I would say that a very fair answer to that is to say that autobiography is the spirit but not the letter of my work. I'm informed by broad things: being a man, being someone's son and someone's father, someone's husband, being an employee at a large corporation, being a man who's been sick-I don't mean to say I've been sick; at worst I've had a terrible cold, you know? In other words I have the same broad range of experiences as any other human being. My predilection, though, is to write about that, and I'm not convinced that my broad range of experience deviates much from 
the norm. The transcription of my personal life would probably read a lot like the babble of a bunch of dullards, but at the same time it informs nearly everything that I write. So it's difficult to understand what that tension is and how the fiction that I write, which is, decidedly, un-autobiographical, is informed by my biography.

TA: Do you think writing fiction today is very different from writing fiction in the past? For instance, how are the concerns of writers today different from those who wrote at the height of Modernism?

JF: I would think the concerns of today are certainly very different from those of High Modernism - that seems like an absurd premise to argue againstbut it seems absurd to argue against some fairly fundamental human instincts that have remained steady for a hundred, two hundred, many hundreds of years. Otherwise, to read Joyce's "The Dead," for example, would mean nothing, would mean somehow less than it did at the time. And I can't imagine that, because it resounds with such beauty and perfection now that I doubt it could have been any better during Joyce's time or people would have died reading it. So I think the answer is a kind of compromise between the two things.

If you're asking for a kind of synthesizing evaluation of where fiction is now, I can't give you one, but I can say that the suit remains the same, elements being enchantment, truth-telling, beauty, sublimation of experience and loss, and many other things that are still operating.

One of the difficult things, of course, is overcoming one's sense of belatedness. This can be as much of a struggle as the inherent challenges of writing anything good. If you think that everything's been done, it's hard to get up in the morning. So when I.read Beckett and then I add him to Proust and add him to Nabokov, it starts to equal despair. Where do you go after Beckett? I don't know if you can go too terribly far, but I think it's a damn worthwhile goal to try. 